\title{
Strategy To Poverty Alleviation Throught The Gampong Fund Allocation Program In Aceh Besar District
}

\author{
Sufitrayati $^{1}$, Fanny Nailufar ${ }^{2}$, Aliasuddin $^{3}$ and T. Zulham ${ }^{3}$ \\ \{sufitrayati@serambimekkah.ac.id\} \\ ${ }^{1}$ Departement of Accounting, Universitas Serambi Mekkah, Aceh Indonesia \\ ${ }^{2}$ Departement of Management, Universitas Serambi Mekkah, Aceh Indonesia \\ ${ }^{3}$ Departement of Economics and Business, Universitas Syiah Kuala, Aceh Indonesia
}

\begin{abstract}
This study aims to find out poverty alleviation strategy through the Gampong Fund Allocation Program (ADG) and poverty alleviation efforts through increasing ADG absorption capacity in underdeveloped villages in Aceh Besar District. In this research use qualitative descriptive analysis method. Research data consist of primary data and secondary data. The data used in this study is primary data (primary data) by conducting interviews of respondents ie community and village tools and using a list of questions that have been prepared before and secondary data (secondary data) sourced from the Central Bureau of Statistics (BPS) and institutions is in Aceh Besar District. The results showed that the absorption capacity of the Gampong Fund Allocation Program in Aceh Besar District is very varied. Establishment of ADG in Aceh Besar District increases annually. Generally allocation of gampong funds is allocated or its use is more widely used for gampong apparatus or usually called wage jerih. It is therefore expected that local governments can develop a more flexible and non-standardized qanun. Providing an opportunity for the community to be involved in the preparation of the ADG program so as to encourage the community to live a decent life in solving the economic problems in the region so as to have a real impact on the problem of regional poverty.
\end{abstract}

Keywords: Strategy, poverty, gampong fund allocation

\section{Introduction}

Poverty is a very complex and multidimensional problem that not only deals with economic issues but also deals with non-economic issues such as politics, social, culture, assets, and the environment. This indicates the ineffectiveness of most of the poverty alleviation programs currently being proclaimed by the government. Basically the achievement of the welfare of the community is passed by way of life changes to a better life than before.

This is done through the development of society that is improving the economic, social, and cultural conditions of society, so that poverty and the environment of society will 
experience a change to a better direction. Direct assistance such as the Gampong Dana Allocation (ADG) program is a concrete form of district government policy in the effort to develop the village, with this support expected to improve living standards in rural communities. Local governments are expected to focus their budgets to solve these poverty problems. Therefore, poverty alleviation assistance programs at the local level should be a priority and clearly reflected in the Regional Budget (APBD).

\section{Literature}

\subsection{Poverty}

Poverty is a condition of economic inability to meet the average standard of living of people in an area. This condition of disability is characterized by low income ability to meet basic needs in the form of food, clothing, and boards. This low income capability will also reduce the ability to meet the average living standards such as public health standards and education standards. The so-called poor condition of society can be identified by the ability of income to meet the standard of living [1].

In principle, the standard of living in a society is not just enough food for the need, but also the need for health and education. Adequate residence or settlement is one of the standard of living or standard of community welfare in an area. Under this condition, a society is called poor if it has a much lower income than the average income so that there is not much opportunity to prosper itself [2].

\subsubsection{Poverty is seen as a multidimensional form}

Based on the condition of poverty that is seen as a form of multidimensional problems, poverty has 4 forms. The four forms of poverty are [2]:

1. Absolute Poverty

Absolute poverty is a condition in which the income of a person or group of people is below the poverty line so that it is insufficient to meet the standard needs for food, clothing, health, housing, and education needed to improve the quality of life.

2. Relative Poverty

Relative poverty is defined as a form of poverty that occurs because of the influence of development policies that have not reached to all levels of society, causing an imbalance in income or imbalance welfare standards.

3. Cultural Poverty

Cultural poverty is a form of poverty that occurs as a result of the attitudes and habits of a person or society that generally comes from cultures or customs that are relatively unwilling to improve living standards with modern procedures.

4. Structural Poverty

Structural poverty is a form of poverty caused by the lack of access to resources that generally occur in a socio-cultural or socio-political order that is less supportive of the liberation of poverty. 


\subsection{Gampong Fund Allocation (ADG)}

The allocation of direct funds to village is referred to the policy of Gampong Fund Allocation (ADG), which is stipulated in Local Government Regulation No. 7/1986 on Financial Guidance from the District Government to the Gampong Government, that the village finance must be managed effectively, efficiently, economically, transparently and responsibly taking into consideration the principle of compliance and benefit to society. The Gampong Fund Allocation, hereinafter abbreviated as ADG, is the funds allocated by the district government to villages which are sourced from the central and regional finance of balancing funds received by the Regency. Regional Tax Revenue Funds and Retribution Area funds that are allocated by the district government for villages sourced from the share of District Tax and District Retribution received by the District. Thus, the Gamppong Fund Allocation (ADG) is a fund allocated by the District Government for villages which sourced from the balancing funds and which received by villages.

\subsubsection{The Management of Gampong Fund Allocation (ADG)}

Financial Management of Gampong Fund Allocation (ADG) is an inseparable part of the Village Finance Management in the Village, therefore in Fund Management of Gampong Fund Allocation (ADG) must comply with the Village Fund Allocation Management Principles as follows: APBG.

ADG management is an integral part of the financial management of village funds in

All activities to be funded by ADG are planned, implemented and evaluated openly by involving all elements of the community in village.

All activities must be accountable administratively, technically and legally. Gampong Fund Allocation (ADG) is implemented by using the principles of efficient and controlled direction.

\section{Methods}

\subsection{Research Location}

Besides divided the region into 3 (three) parts of the West, Central / Eastern Region and Northern Region and also divided the region based on the amount of ADG received. Therefore, the research sample was also divided into 3 (three) parts; the region with large, medium and small ADG.

\subsection{Research methods}

This research uses descriptive qualitative analysis method. Research data consist of primary data and secondary data. Primary data were obtained through interviews, questionnaires and observations. 


\subsection{Data Analysis Research}

With the effort to collect data from various sources so that the necessary data can be collected optimally. The data collected through the questionnaire were processed by using descriptive statistics and presented in percentage form in order to produce indicators in each problem explained.

\section{Results and Discutions}

\subsection{Poverty Eradication Strategy Through the Absorption Ability of Gampong Fund (ADG) in Aceh Besar District}

The ADG absorption in Aceh Besar Regency is very varied. Establishment of ADG in Aceh Besar District increases annually. This is determined by several factors, including the wide area of gampong and the increasing number of head of household (KK) in the gampong. The following recapitulates the number of ADGs in Aceh Besar District in Table 1.

Table 1. Recapitulation of Gampong Fund Allocation (ADG) Regency of Aceh Besar Year 2014-2016

\begin{tabular}{llll}
\hline Districts & ADG 2014 & ADG 2015 & ADG 2016 \\
\hline Darul Imarah & 2.050 .751 .000 & 4.220 .041 .000 & 5.863 .836 .000 \\
Peukan Bada & 1.548 .217 .000 & 3.077 .487 .000 & 4.241 .171 .000 \\
Darul Kamal & 820.598 .000 & 1.679 .948 .000 & 3.230 .954 .000 \\
Indrapuri & 2.980 .357 .000 & 6.034 .648 .000 & 5.929 .811 .000 \\
Simpang Tiga & 1.002 .705 .000 & 2.014 .187 .000 & 3.599 .171 .000 \\
Kuta Malaka & 890.004 .000 & 1.741 .029 .000 & 1.990 .005 .000 \\
Kuta Baro & 2.717 .952 .000 & 5.477 .502 .000 & 1.694 .711 .000 \\
Darussalam & 1.726 .468 .000 & 3.508 .743 .000 & 1.817 .863 .000 \\
Baitussalam & 841.912 .000 & 1.734 .116 .000 & 5.963 .836 .000 \\
\hline
\end{tabular}

Source: Central Bureau of Statistics (BPS) Aceh (Processed)

The location of this study in addition to dividing the region into 3 (three) parts of the West, Central / Eastern Region and Northern Region and also divide the region based on the amount of ADG received. Therefore, the research sample is also divided into 3 (three) parts ie the region with large, medium and small ADG. The following divisions of the region can be seen in Table 2.

Table 2. Subdivision of Kecamatan Research Sites Based on Group of ADG Total in Aceh Besar District 2015

\begin{tabular}{|c|c|c|c|c|c|c|}
\hline Region & \multicolumn{2}{|c|}{ Large Fund Group } & \multicolumn{2}{|c|}{ Medium Fund Group } & \multicolumn{2}{|c|}{ Small Fund Group } \\
\hline & Districts & Total of ADG & Districts & Total ofADG & Districts & Total ADG \\
\hline West & $\begin{array}{l}\text { Darul } \\
\text { Imarah }\end{array}$ & 2.050 .751 .000 & $\begin{array}{l}\text { Peukan } \\
\text { Bada }\end{array}$ & 1.548 .217 .000 & $\begin{array}{l}\text { Darul } \\
\text { Kamal }\end{array}$ & 820.598 .000 \\
\hline Central/East & Indrapuri & 2.980 .357 .000 & $\begin{array}{l}\text { Simpang } \\
\text { Tiga }\end{array}$ & 1.002 .705 .000 & $\begin{array}{l}\text { Kuta } \\
\text { Malaka }\end{array}$ & 870.004 .000 \\
\hline Nouth & Kuta & 2.717 .952 .000 & Darussalam & 1.726 .468 .000 & Baitussalam & 841.912 .000 \\
\hline
\end{tabular}




\begin{tabular}{l} 
Region $\begin{array}{l}\text { Large Fund Group } \\
\text { Baro }\end{array}$ \\
\hline Source: Central Bureau of Statistics (BPS) Aceh [3] \\
In accordance with table 4.2 above can be seen that each district in Aceh Besar District \\
get different amounts of funds in the Allocation Fund Gampong (ADG). As it is known that \\
ADG is sourced from 10 percent of Aceh Besar General Allocation Fund (DAU) which is then \\
added with 10 percent of Taxes and Area Restribusi. In the allocation of gampong funds done \\
fairly and equitably, which means that is divided proportionally for each gampong based on \\
the value of gampong weight. \\
In the channeling of gampong funds have a mechanism that there are 4 stages with each \\
25 percent. The disbursement of ADG is carried out through Bank Aceh, which is shown by \\
the local government where every phase of fund disbursement should be accompanied by the \\
recommendation of the Sub-district Head and the subsequent disbursement of funds after the \\
gampong prepare the Consumer Accountability Report (LPJ) for the next quarter. Thus each \\
gampong must prepare a monthly report to account for the realization of ADG users and all \\
expenditures on the use of the Gampong Fund on the conformity between LPJ and Qanun \\
issued by the local government of Kabupaten Aceh Besar.
\end{tabular}

\subsection{Poverty Alleviation Efforts through Increasing the Absorption Ability of Village Gampong Allocation (ADG) in Disadvantaged Villages in Aceh Besar District}

In the Year 2015 recorded that the population in Aceh Besar district is 392.584 people, can be estimated population density reached 135 people / $\mathrm{Km} 2$, and the rate of population growth reached $4.02 \%$. In the same year the number of poor can reach 62,270 people, with a poverty line of Rp. 366,676 per capita / month and poor level 15,93\%. The number of poor people in Aceh Besar district from year to year experienced a relatively satisfactory decline. This can be seen in the following table (Table 3 ).

Table 3. Number of Poor People (Thousand Soul) in Aceh Besar District

\begin{tabular}{cc}
\hline Years & $\begin{array}{c}\text { Number of Poor People } \\
\text { (Thousand Souls) }\end{array}$ \\
\hline 2014 & 62.37 \\
2015 & 62.27 \\
2016 & 62.03 \\
\hline Source: Central Bureau of Statistics (BPS) Aceh [4]
\end{tabular}

The provision of direct assistance in the form of Gampong Fund Allocation (ADG) and sourced from APBK becomes a real form of government policy in an effort to develop gampong by supporting the improvement of physical infrastructure and non-physical village. With this support is expected to increase the standard of living in gampong communities, where all parties namely the village community also took part in the development of the village. The allocation of funds is also used in the empowerment of rural communities to improve the power of the community towards an independent community condition. 


\section{CONCLUTION}

We hope you find the information in this template useful in the preparation of your submission. Based on the results of research can be concluded that:

The ADG received by the Gampong Government is used for the Permanent Income of Keuchik and the Village Apparatus, the Keuchik Allowance and the Village Apparatus, the Tuha Peut Gampong Allowance, other Gampong Allowances, the Orphan Support and the Pre-Prosperous Family Rice Transports, and other expenditures.

Direct assistance in the form of Gampong Fund (ADG) allocation and sourced from APBK becomes the real form of government policy in the effort to develop gampong by supporting the improvement of physical infrastructure and non-physical village. With this support is expected to increase the standard of living in the community gampong.

\section{References}

[1] H. Nugroho, Kemiskinan, Ketimpangan, dan Kesenjangan. Yogyakarta: Aditya Media, 1995

[2] C. Suryawati, "Memahami kemiskinan secara multidimensional," J. Manaj. Pelayanan Kesehat., vol. 8, no. 3, 2005.

[3] Badan Pusat Statistik, Aceh Besar Dalam Angka Tahun 2015. BPS Provinsi Aceh, 2016.

[4] Badan Pusat Statistik, Aceh Besar Dalam Angka Tahun 2016. BPS Provinsi Aceh, 2017. 